\title{
Peter De Leon's Commitment to Democracy
}

Helen Ingram

\section{OpenEdition}

\section{Journals}

Electronic version

URL: http://journals.openedition.org/irpp/1197

DOI: $10.4000 /$ irpp. 1197

ISSN: 2706-6274

\section{Publisher}

International Public Policy Association

\section{Printed version}

Date of publication: 1 September 2020

Number of pages: 129-130

ISSN: 2679-3873

\section{Electronic reference}

Helen Ingram, "Peter De Leon's Commitment to Democracy", International Review of Public Policy [Online], 2:2 | 2020, Online since 01 September 2020, connection on 29 January 2021. URL: http:// journals.openedition.org/irpp/1197 ; DOI: https://doi.org/10.4000/irpp.1197

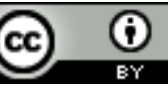

International Review of Public Policy is licensed under a Creative Commons Attribution 4.0 International. 


\section{Peter De Leon's Commitment to Democracy}

\section{Helen Ingram}

University of Arizona and the University of California in Irvine

I first encountered the work of policy scholar Peter de Leon in the late 1970s when the interdisciplinary field of public policy was just emerging. As a beginning professor I read his chapter on policy termination, in the 1979 book on the policy cycle edited by May and Wildavsky. A few years later, I joined a packed audience to hear him speak about his ideas of the policy stages and cycle analyses, where he described the policy process as occurring through a sequence of stages: agenda setting, policy formulation, policy adoption, implementation, evaluation, and termination (Brewer and de Leon 1983; de Leon 1999). These ideas, which departed radically from a prevailing focus on means/ends reasoning, influenced me greatly, leading me to call myself a policy scholar for the rest of my career.

Profesor de Leon built an illustrious record of research in public policy. Indeed, he was one of a handful of intellectual founders of the sub-field of public policy studies within political science, and his work has had national and international impact. A principle element in this legacy is his insistence that students of public policy concentrate on democracy, a criterion that transcended the field's early focus on efficiency and effectiveness. Interpretive analysis is often the most appropriate methodology for value-centered policy studies, and de Leon's work helped legitimize its use. Peter de Leon displayed a life-long commitment to new ideas, constantly learning new things and contributing a broad body of work. Although dubious when they first emerged, Peter de Leon eventually embraced social construction approaches. I am forever grateful for my opportunities to collaborate, which included most recently (2016) a chapter entitled "Public Policy Theory: The Elephant in the Corner." I also appreciate the many scholarly lessons he taught generations of graduate students and fellow researchers.

Every student of public policy should be familiar with Peter de Leon's work. In my fifty years of teaching, something by de Leon was always on my syllabus. Among the publications that I most loved to assign was "Democratic Values in the Policy Sciences," which appeared in the American Journal of Political Science in 1995. In that article, de Leon argued that the policy sciences were excessively technocratic and neglected the Tocqueville notion of participatory democracy. Policy sciences, he wrote, have served a Madisonian idea of pluralist democracy that removes the people from policy making, and assigns governance to elites as a matter of a "balancing of interests." This pluralist democracy is thin and often unfair. In the course of his argument, Professor de Leon drew upon a wide variety of classical and contemporary political theorists and policy analysts. In a 2002 article authored with his wife Linda de Leon, he argued that implementation theory requires a sound understanding of the contingencies that govern a choice of strategies. These articles are part of an encompassing democracy and public policy research agenda that spans decades and includes books and dozens of articles and book chapters.

Peter de Leon documented the history of public policy as an area of study and was the foremost student of the writings of Harold Lasswell, its founder. It is gratifying that in 2000, the Policy Studies Organization presented him with the Harold D. Lasswell Award, for being "an out- 
standing scholar in contributing to our understanding of the substance and process of public policy." His presentation of policy history was always evenhanded and thorough, never privileging certain research templates or models including those to which he associated himself.

More rare than diamonds among policy scholars, Peter de Leon was a wonderful writer, employing just the right simile and turn of phrase. The colorful and engaging scholarship of Peter de Leon drew talent to the field. He left so many of us grateful for what he gave us but wishing for more.

Brewer, G. D., \& deLeon, P. (1983). The foundations of Policy Analysis. Monterey, CA: Brooks/Cole.

DeLeon, P., \& DeLeon, L. (2002). What Ever Happened to Policy Implementation? An Alternative Approach. Journal of Public Administration Research and Theory, 12(4), 467-492. https://doi.org/10.1093/oxfordjournals.jpart.a003544

De Leon, P. (1999). The Stages Approach to the Policy Process: What has it Done? Where is it Going?. In P. A. Sabatier (Ed.), Theories of the policy process (pp. 19-34). Boulder, CO: Westview Press.

Ingram, H, deLeon, P., \& Schneider, A.L. (2016). Conclusion: Public Policy Theory: the Elephant in the Corner. In B.G Peters \& P. Zittoun (Eds.), Contemporary Policy Approaches, Theories, Controversies, and Perspectives (pp. 175-200). London: Palgrave Macmillan.

May, J.V., \& Wildavsky, A.B, (1978). The Policy cycle. Beverly Hills, CA: Sage Publications. 